\title{
Apoptotic Effect of Tolfenamic Acid in KB Human Oral Cancer Cells: Possible Involvement of the p38 MAPK Pathway
}

\author{
Jun-Hee Kim ${ }^{1, * *}$, Ji-Youn Jung ${ }^{2, * *}$, Jung-Hyun Shim ${ }^{1}$, Jin Kim², Kyeong-Hee Choi ${ }^{1}$, Ji-Ae Shin ${ }^{1}$, \\ Eun-Sun Choi ${ }^{1}$, Syng-Ook Lee ${ }^{3}$, Sudhakar Chintharlapalli ${ }^{3}$, Ki Han Kwon ${ }^{4}$, Dae-Ho Leem ${ }^{5}$, \\ Nam-Pyo Cho ${ }^{1, *}$ and Sung-Dae Cho ${ }^{1,6, *}$ \\ ${ }^{1}$ Department of Oral Pathology, School of Dentistry and Institute of Oral Bioscience, Brain Korea 21 project, \\ Chonbuk National University, Jeonju 561-756, Republic of Korea \\ ${ }^{2}$ Department of Companion and Laboratory Animal Science, Kongju National University, \\ Yesan 340-702, Republic of Korea \\ ${ }^{3}$ Institute of Biosciences and Technology, Texas A\&M University Health Science Center, \\ 2121 W. Holcombe Blvd., Houston, TX, 77030, USA \\ ${ }^{4}$ Department of Food Science and Nutrition, College of Health, Social Welfare and Education, Gwangju University, \\ Gwangju 503-703, Republic of Korea \\ ${ }^{5}$ Department of Oral and Maxillofacial Surgery, School of Dentistry and Research of Clinical Medicine, \\ Chonbuk National University, Jeonju 561-756, Republic of Korea \\ ${ }^{6}$ Laboratory for Oral disease-related Compounds, Chonbuk National University, \\ Jeonju 561-756, Republic of Korea
}

Received 12 January, 2010; Accepted 21 March, 2010; Published online 17 June, 2010

\begin{abstract}
Summary Nonsteroidal anti-inflammatory drugs (NSAIDs) are known to inhibit cancer growth by inhibiting the activity of cyclooxygenase (COX). However, there is increasing evidence that the COX-independent pathway may be also involved in the inhibitory effect of NSAIDs against tumor progression. Tolfenamic acid is a NSAID that exhibits anticancer activity in pancreatic and colorectal cancer models. In the present study, the anti-tumor effect of tolfenamic acid in KB human oral cancer cells is investigated. The results showed that tolfenamic acid does not alter the expression of the COX proteins, but it inhibits cell growth and induces apoptosis as evidenced by the annexin $\mathrm{V}$ positivity, sub-G1 population, nuclear fragmentation and the cleavage of poly ADP-ribose polymerase. In addition, tolfenamic acid also leads to a loss of the mitochondrial membrane potential in KB cells. These effects are related to the activation of $\mathrm{p38}$ mitogen-activated protein kinase (MAPK) pathway. These results suggest that tolfenamic acid-induced apoptotic cell death inhibits cancer growth by activating the p38 MAPK pathway for cancer prevention.
\end{abstract}

Key Words: KB human oral cancer cells, tolfenamic acid, mitochondrial membrane potential, apoptosis, p38 MAPK

\footnotetext{
*To whom correspondence should be addressed.

Sung-Dae Cho Tel: +82-63-270-4027 Fax: +82-63-270-4025

E-mail: efiwdsc@chonbuk.ac.kr

Nam-Pyo Cho Tel: +82-63-270-4026 Fax:+82-63-270-4025

E-mail: npcho@chonbuk.ac.kr

**Both authors contributed equally to this paper.
}

\section{Introduction}

Non-steroidal anti-inflammatory drugs (NSAIDs) have traditionally been used as non-prescription analgesics [1] and can be separated into two classes of NSAIDs: classical NSAIDs and cyclooxygenase (COX)-2 inhibitors. All 
classical NSAIDs can inhibit both COX-1 and COX-2 and selective COX-2 inhibitors bind selectively to COX-2 to reduce prostaglandin synthesis. It is known that chronic patients who use NSAIDs can develop gastric ulcers or gastrointestinal complications. These side effects can be explained by the inhibition of COX-1 and cause a major health problem implying that drug efficacy of a COX-2 inhibitor is promising [2].

There is increasing epidemiological and experimental evidence that these agents have a protective effect in coronary heart disease, as well as certain cancers. Although many questions are still remained to be answered, there are numerous evidences suggesting that the enzyme COX-2 is involved in the development and growth of cancers. Liu et al. [3] first reported that COX-2 over-expression induces tumorigenesis by inserting the murine COX-2 gene into rat mammary gland epithelial cells. Some more evidences showed that COX-2 is over-expressed in a variety of human solid cancers compared to normal tissues [4-12]. NSAIDs can be used as chemopreventive agents because the potential mechanism of action for NSAIDs is to inhibit COX activity. Recently, it was reported that NSAIDs have other targets in addition to COX-2. He et al. [13] reported that the peroxysome proliferation activating receptor delta (PPAR $\delta$ ) is also an APC-regulated target of NSAIDs. In addition, NSAIDs metabolites can suppress the nuclear factor- $\mathrm{KB}(\mathrm{NF}-\kappa \mathrm{B})$ survival signal via I $\kappa B$ kinase $\alpha(\mathrm{I} \kappa \mathrm{K} \alpha)$ inhibition [14]. These suggest that NSAIDs inhibit tumor growth in a COXdependent and -independent pathway. Tolfenamic acid is a potent, well-tolerated NSAID with a low gastric side effect and high therapeutic index [15]. It possesses antipyretic and analgesic activities as evidenced in several animal models and has shown promising results in long-term treatment of osteoarthritis, rheumatoid arthritis and migraine [16, 17]. Recently, tolfenamic acid also affects apoptosis in colorectal cancer cells as well as metastasis and tumorigenesis in pancreatic cancer models $[4,18,19]$.

The $\mathrm{p} 38$ mitogen-activated protein kinase (MAPK) has been reported to be associated with the induction of apoptosis in several cell types [20]. Moreover, the activation of p38 MAPK damages the mitochondrial function by altering the B-Cell Leukemia 2 (Bcl-2) family protein [21]. Therefore, p38 MAPK is a critical signaling pathway in the complexing signaling events of apoptotic cell death. However, there are no reports on the p38 MAPK activated by tolfenamic acid for apoptosis. Therefore, studies in this laboratory examined the effect and mechanism of tolfenamic acid on the growth of KB cells.

\section{Materials and Methods}

Reagents

The poly ADP-ribose polymerase (PARP) antibody was
A<smiles>Cc1c(Cl)cccc1Nc1ccccc1C(=O)O</smiles>

B

Tolfenamic $\operatorname{acid}(\mu \mathrm{M}) \quad 0 \quad 50 \quad 75 \quad 100$

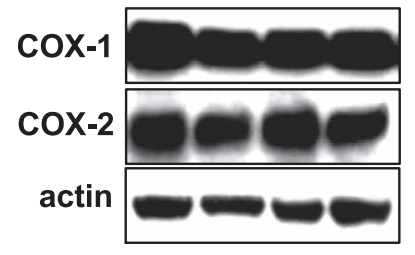

C

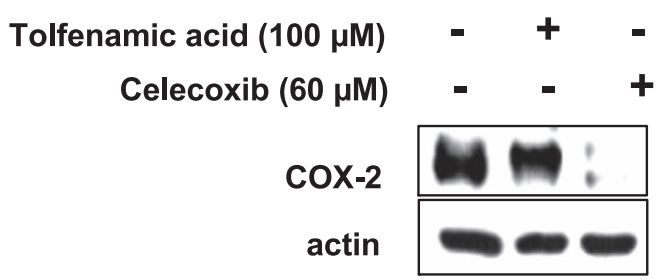

Fig. 1. A, The structure of tolfenamic acid; B, The effect of 50, 75 and $100 \mu \mathrm{M}$ of tolfenamic acid (one of nonsteroidal anti-inflammatory drugs (NSAIDs) for $48 \mathrm{~h}$ on the expressions of cyclooxygenase (COX) proteins in $\mathrm{KB}$ cells. Immunoblot detection of the COX-1 and COX-2 proteins in whole cell lysates. $\mathrm{C}$, Immunoblot detection of COX-2 protein in whole cell lysates treated with dimethyl sulfoxide (DMSO), $100 \mu \mathrm{M}$ of tolfenamic acid, and $60 \mu \mathrm{M}$ of Celecoxib. Actin was used to normalize the protein loading from each treatment.

obtained from BD Pharmingen ${ }^{\mathrm{TM}}$ (San Jose, CA). The antibody for COX-1 and actin was purchased from Santa Cruz Biotechnology (Santa Cruz, CA). The COX-2 antibody was purchased from Cayman (Ann Arbor, MI). The antibodies for phosphor-p38 and total p38 were supplied by Cell Signaling Technology (Beverly, MA). SB203580 and Propidium Iodide were obtained Calbiochem (San Diego, $\mathrm{CA})$ and RNase A was obtained from Sigma-Aldrich Korea (Yongin city, Korea). Tolfenamic acid (Fig. 1A) was purchased from Dae He Chemical Co. (Shihung, Korea).

\section{Cell culture and drug treatment}

The KB human oral cancer cells were obtained from the American Tissue Culture Collection (Manassas, VA) and cultured at $37^{\circ} \mathrm{C}$, in Dulbecco's modified essential medium 
(DMEM) containing 5\% fetal bovine serum (FBS) and $100 \mathrm{U} / \mathrm{ml}$ each of penicillin and streptomycin in a $5 \% \mathrm{CO}_{2}$ atmosphere. An equal number of cells were seeded and allowed to attach. The cells were treated with dimethyl sulfoxide (DMSO) $(0.1 \%)$ or tolfenamic acid $(50,75$ and $100 \mu \mathrm{M}$ ) diluted in DMEM with 2.5\% FBS for $48 \mathrm{~h}$.

\section{Cell proliferation assay}

The KB cells were counted to examine the effects of 50 , 75 and $100 \mu \mathrm{M}$ of tolfenamic acid for $48 \mathrm{~h}$ on the number of viable cells. The cell count was carried out using a hematocytometer with trypan blue $(0.4 \%)$. Each experiment was performed in triplicate and the results are expressed as the means $\pm \mathrm{SD}$ for each treatment group.

\section{MTT Assay}

A MTT assay kit (Sigma-Aldrich Korea, St. Louis, MO) was used to examine the effect of 50,75 and $100 \mu \mathrm{M}$ of tolfenamic acid on cell growth in KB cells. In brief, after the treatment of tolfenamic acid for $48 \mathrm{~h}, 20 \mu \mathrm{l}$ of a MTT solution $(2 \mathrm{mg} / \mathrm{ml})$ was added to each well and the cells were incubated for $2 \mathrm{~h}$ at $37^{\circ} \mathrm{C}$. The supernatant was removed and $100 \mu \mathrm{l}$ of DMSO was added to each well to dissolve the water insoluble purple formazan crystals. The formazan absorbance was measured at $560 \mathrm{~nm}$. All the measurements were carried out in triplicate. The results are expressed as the percentages proliferation with respect to the DMSO-treated cells.

\section{Western blot analysis}

The whole cell lysates were extracted using a lysis buffer and the protein was quantified using the Bradford protein assay. The protein samples were size-separated by electrophoresis on SDS-polyacrylamide gels and the separated proteins were electroblotted onto nitrocellulose membranes. The blot was blocked in 5\% skim milk for $1 \mathrm{~h}$ at room temperature (RT), and incubated with the primary antibody overnight at $4^{\circ} \mathrm{C}$. Incubation with a HRP-conjugated secondary antibody was then carried out at RT for $4 \mathrm{~h}$. The antibody-bound proteins were detected using an ECL Western blotting analysis system.

\section{FACS Analysis for Sub-G1 DNA Measurement}

After treatment with 75 and $100 \mu \mathrm{M}$ of tolfenamic acid for $48 \mathrm{~h}$, the detached $\mathrm{KB}$ cells were collected and combined with the adherent cells that had been released by trypsinization. The cells were fixed in $70 \%$ ethanol overnight at $-20^{\circ} \mathrm{C}$. Then, the cells were then subsequently stained with $0.02 \mathrm{mg} / \mathrm{ml}$ propidium iodide (PI) and subjected to DNA content analysis using a FACScan cytometer.

Determination of apoptosis induction using Annexin V-FITC

The induction of apoptosis was determined using the
Annexin V-FITC Apoptosis Detection method. The KB cells were collected, washed with phosphate buffered saline (PBS) and assayed for the presence of extracellular phosphatidylserine using a conjugated Annexin V-FITC antibody with propidium iodide (PI). The results were performed using a FACScan cytometer.

\section{4'-6-diamidino-2-phenylindole (DAPI) staining}

The level of cell death was measured by DAPI staining (Sigma Chemical Co, MO). After the experimental treatment with 75 and $100 \mu \mathrm{M}$ of tolfenamic acid for $48 \mathrm{~h}$, the $\mathrm{KB}$ cells were harvested by trypsinization and fixed in $4 \%$ paraformaldehyde at RT for $20 \mathrm{~min}$. The cells were resuspended in PBS, deposited them on poly-L-lysin-coated slides, stained with a DAPI solution $(2 \mu \mathrm{g} / \mathrm{ml})$ and viewed under a fluorescence microscope.

\section{JC-1 assay}

The mitochondrial membrane potential was measured using 3,3'-tetraethylbenzimidazolylcarbocyanine iodide (JC1) (Stratagene, La Jolla, CA). KB cells were exposed to 50,75 and $100 \mu \mathrm{M}$ of tolfenamic acid for $48 \mathrm{~h}$ and then incubated with $1 \mathrm{X} \mathrm{JC}-1$ at $37^{\circ} \mathrm{C}$ for $30 \mathrm{~min}$ and washed with PBS (3X). The green cytoplasmic JC-1 fluorescence was measured using a FACScan cytometer.

\section{Statistical analysis}

The statistical significance was assessed using a Student's $t$ test. A $p$ value $<0.05$ compared with the solvent control was considered statistically significant.

\section{Results}

\section{The effect of tolfenamic acid on COXs}

Because tolfenamic acid is a NSAID, it was tested to determine if it affects the expression of COX proteins. KB cells were incubated in various concentrations $(50,75$ and $100 \mu \mathrm{M}$ ) for $48 \mathrm{~h}$, and examined by western blot analysis (Fig. 1B). Tolfenamic acid did not decrease the levels of the COX-1 and COX-2 proteins. To confirm that it does not decrease the level of COX-2 protein, Celecoxib, a specific COX-2 inhibitor was used. Even though Celecoxib decreased the level of COX-2 protein, tolfenamic acid did not affect it (Fig. 1C).

\section{Tolfenamic acid-induced growth inhibitory activity in $K B$ cells}

To examine if tolfenamic acid inhibited KB cell growth, the $\mathrm{KB}$ cells were treated with various concentration of tolfenamic acid for $48 \mathrm{~h}$ and then the morphological changes were observed by optical microscopy (Fig. 2A). The tolfenamic acid-treated cells were detached and rounded-up in a concentration-dependent manner. MTT assay and viable 
A

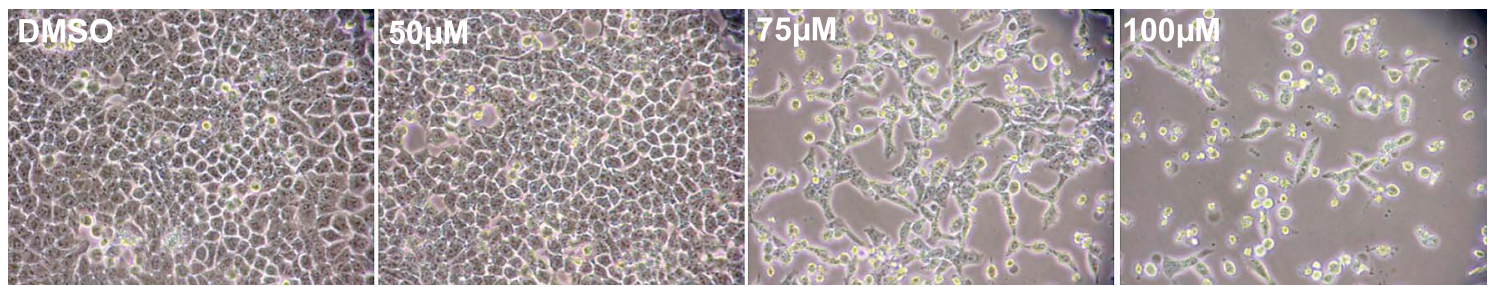

B

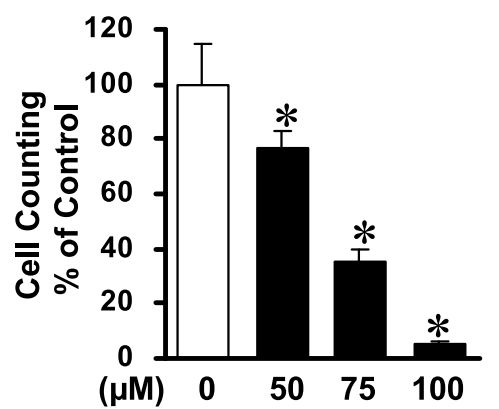

C

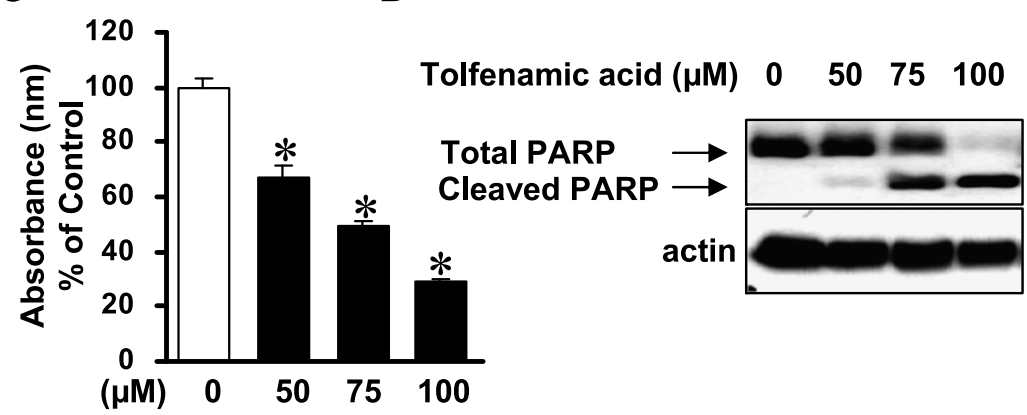

Fig. 2. The effect of tolfenamic acid on cell growth in KB cells. A, Photomicrographs of KB cells treated with 50,75 and $100 \mu \mathrm{M}$ of tolfenamic acid for $48 \mathrm{~h}$. The KB cells were treated with DMSO (vehicle control) or various concentrations of tolfenamic acid for $48 \mathrm{~h}$ and then observed by optical microscopy. B, The KB cells were treated with DMSO or various concentrations of 50, 75 and $100 \mu \mathrm{M}$ of tolfenamic acid for $48 \mathrm{~h}$. Cell proliferation was determined using a trypan blue exclusion assay. The points are the mean $\pm \mathrm{SD}$ of three independent experiments. ${ }^{*} p<0.05$ compared to the control group. $\mathrm{C}$, The cell viability of KB cells was estimated using a MTT assay. The points are the mean \pm SD of three independent experiments. ${ }^{*} p<0.05$ compared to the control group. D, The apoptotic effect of tolfenamic acid in KB cells. Immunoblot detection of the cleaved poly ADP-ribose polymerase (PARP) in whole cell lysates. Actin was used to normalize the protein loading from each treatment.

cell counting were performed to investigate the inhibitory effects of tolfenamic acid (Fig. 2B and C). 50, 75 and $100 \mu \mathrm{M}$ of tolfenamic acid for $48 \mathrm{~h}$ significantly inhibited the growth of $\mathrm{KB}$ cells in a concentration-dependent manner and the $\mathrm{IC}_{50}$ value of tolfenamic acid in $\mathrm{KB}$ cells was $54.9 \mu \mathrm{M}$.

\section{Induction of apoptosis by tolfenamic acid in KB cells}

To determine if tolfenamic acid induced apoptosis of the $\mathrm{KB}$ cells, the level of poly ADP-ribose polymerase (PARP) cleavage was examined by Western blot anlaysis (Fig. 2D). After the tolfenamic acid treatment for $48 \mathrm{~h}$, the cleaved PARP $(85 \mathrm{kDa})$ was clearly detected in the cells exposed to 75 and $100 \mu \mathrm{M}$ of tolfenamic acid whereas the cleaved PARP was not observed in DMSO-treated KB cells. To confirm the apoptotic activity of tolfenamic acid, other distinct features of apoptosis (e.g. Annexin V positivity, sub-G1 population and nuclear fragmentation using DAPI staining) were examined (Fig. 3). The sub-G $\mathrm{G}_{1}$ peak was not detected in DMSO-treated KB cells. However, $48 \mathrm{~h}$ of exposure to 75 and $100 \mu \mathrm{M}$ of tolfenamic acid in KB cells resulted in cell accumulation in the sub-G $\mathrm{G}_{1}$ phase in a concentration-dependent manner. In addition, 75 and 100 $\mu \mathrm{M}$ of tolfenamic acid increased the number of annexin
V-positive $\mathrm{KB}$ cells and nuclear fragmented cells when compared to the DMSO-treated KB cells. This suggests that apoptotic cell death event contributed to the growthinhibitory effect of tolfenamic acid in KB cells.

The depolarization of mitochondrial membrane potential involved in tolfenamic acid-induced apoptosis

The mitochondrial apoptotic events involved in tolfenamic acid-mediated apoptosis were assessed by examining the depolarization of the mitochondrial membrane potentials (MMPs) (Fig. 4). The results showed that tolfenamic acid depolarized the KB cell MMP $48 \mathrm{~h}$ after treatment in a concentration-dependent manner.

\section{p38 MAPK pathway involved in tolfenamic acid-driven apoptosis}

The likely involvement of the p38 MAPK pathways in the signal transduction of apoptosis and mitochondrial damage in KB cells induced by tolfenamic acid was examined by measuring the levels of phosphorylation of these protein kinases. $100 \mu \mathrm{M}$ of tolfenamic acid activated the p38 pathway (Fig. 5A). Western blot analysis was performed using specific protein kinase inhibitors, SB203580 (p38 MAPK) to determine if the activation of $\mathrm{p} 38$ MAPK are 
A

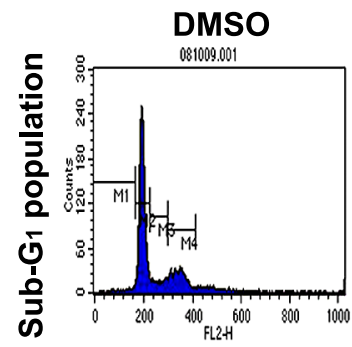

B

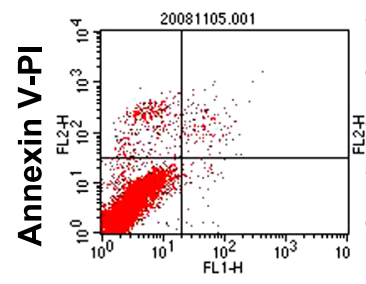

C

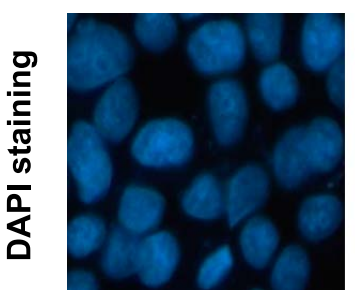

$75 \mu \mathrm{M}$
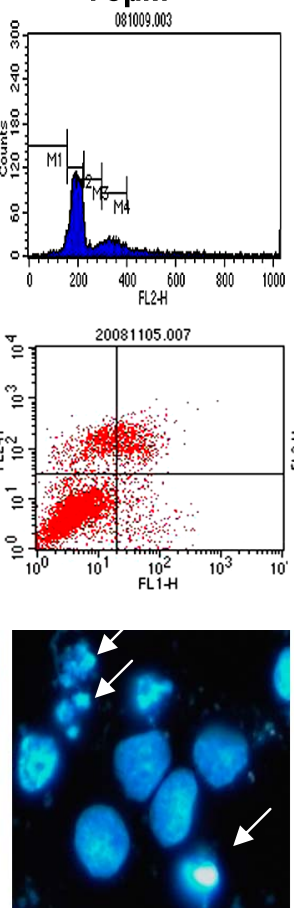

$100 \mu \mathrm{M}$
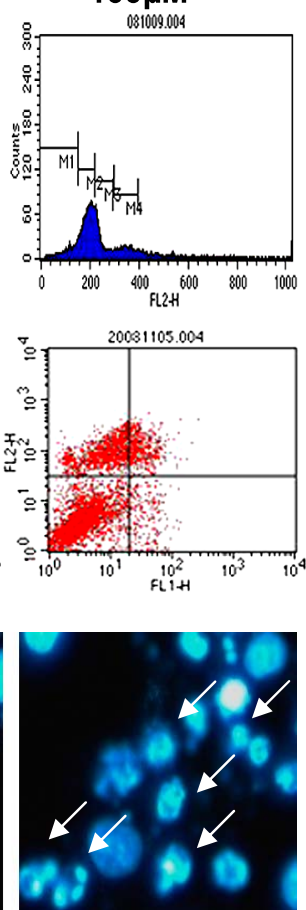

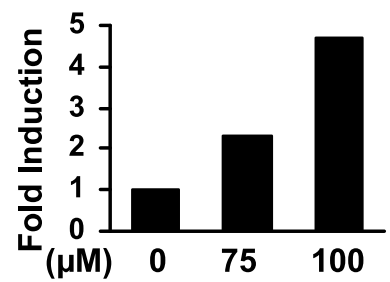

Fig. 3. The effect of tolfenamic acid on apoptotic cell death in KB cells. The KB cells were treated with dimethyl sulfoxide (DMSO) or various concentrations of 75 and $100 \mu \mathrm{M}$ of tolfenamic acid for $48 \mathrm{~h}$. A, The sub-G fraction was assessed by propidium iodide (PI) staining and flow cytometry analysis, Bar graph represents two-independent experiments; B, Annexin V-PI staining was carried out to detect apoptosis, Bar graph represents two-independent experiments; C, Fluorescence microscopy images of the 4'-6-diamidino-2-phenylindole (DAPI)-stained KB cells showing the concentration-dependent appearance of an apoptotic morphology in the tolfenamic acid-treated KB cells. White arrows point nuclear condensation and fragmentation.

involved in tolfenamic acid-induced apoptosis. As expected, SB203580 decreased the tolfenamic acid-induced PARP cleavage (Fig. 5B).

\section{Discussion}

Tolfenamic acid is widely used to treat headache and has exhibited fewer gastrointestinal side effects than other NSAIDs [22]. There is recent evidence suggesting that tolfenamic acid also affects apoptosis in colorectal cancer cells as well as metastasis and tumorigenesis in pancreatic cancer models [4, 18, 19]. Initially, the effect of tolfenamic acid on COX-1 and COX-2 as tested. The data showed that COX-1 and COX-2 proteins were not changed by tolfenamic acid (Fig. 1B) and it is believed that 50, 75 and $100 \mu \mathrm{M}$ of tolfenamic acid for $48 \mathrm{~h}$ is not related to the inhibition of COXs in this cell context even though tolfenamic acid is a NSAID. These results suggest that tolfenamic acidinduced cell growth inhibition in this study might occur in a COX-independent manner. The effects of tolfenamic acid on the growth of KB human cancer cells and the mechanism underlying these effects were then investigated. Tolfenamic acid inhibited the growth of KB cells (Fig. 2). Higher concentration of tolfenamic acid $(100 \mu \mathrm{M})$ resulted in more than $70 \%$ cell death and detached and rounded-up within $48 \mathrm{~h}$ after treatment. In addition, tolfenamic acid induced apoptosis as evidenced by the increased sub-G1 population, annexin $\mathrm{V}$ positivity, nucleosomal fragmentation and cleaved PARP suggesting that apoptosis contributed to the inhibitory effects of tolfenamic acid on the viability of $\mathrm{KB}$ cells (Figs. 2D and 3). These results are in agreement with previous reports in that tolfenamic acid induces PARP cleavage in colorectal cancer cells [19] and pancreatic cancer cells [4].

Mitochondrial damage manifests as an initial hyperpolarization, followed by a loss of the mitochondrial membrane potential and the release of proteins from the mitochondrial intermembrane space such as cytochrome c. Direct and indirect perturbation of the mitochondria can activate the apoptotic pathway. Tolfenamic acid significantly induced the loss of MMP, suggesting that mitochondrial damage is involved in tolfenamic acid-induced apoptosis (Fig. 4). Several studies have demonstrated that the p38 MAPK pathway results in the apoptotic pathway through the loss of MMPs [23-26]. Although several studies already reported that tolfenamic acid induces apoptosis in 
A
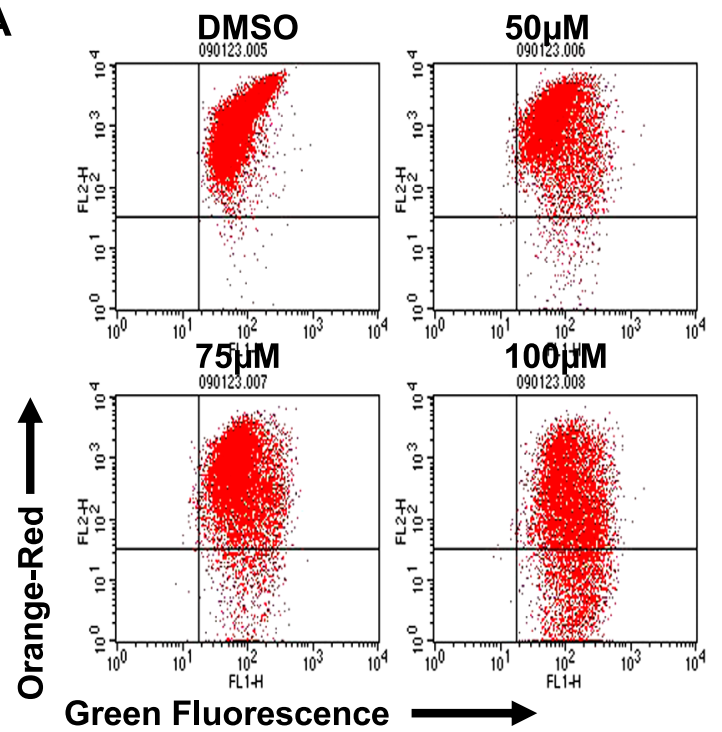

B

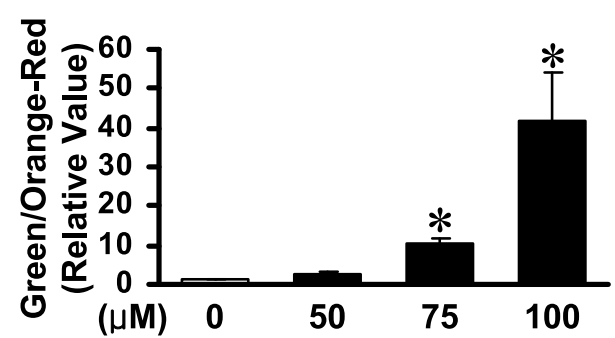

Fig. 4. Tolfenamic acid activates the mitochondrial apoptotic pathway. A, 3,3'-tetraethylbenzimidazolylcarbocyanine iodide (JC-1) assay. After applying 50, 75 and $100 \mu \mathrm{M}$ of tolfenamic acid for $48 \mathrm{~h}$, the JC-1 fluorescence shifted from red-orange to green, indicating depolarization of the mitochondrial membrane potential. B, the points are the mean $\pm \mathrm{SD}$ of three independent experiments. $* p<0.05$ compared to the control group.

cancer cell lines, there is no report on the tolfenamic acidinduced activation of the p38 MAPK signaling pathways $[4,18,19,27]$. Accordingly, this study examined the role of p38 MAPK pathway in tolfenamic acid-induced apoptosis in KB cells. The results showed that tolfenamic acid-induced apoptosis is dependent on the p38 MAPK signaling pathway and plays a key role in inducing apoptotic cell death. However, $75 \mu \mathrm{M}$ of tolfenamic acid did not activate p38 MAPK pathway whereas the same concentration does cleave PARP. This suggests that other mechanism as well as p38 MAPK may be involved in tolfenamic acid-induced apoptosis. Recently, Safe's group reported that specificity protein $1(\mathrm{Sp} 1)$ is degraded by tolfenamic acid to inhibit several cancer cell lines including pancreatic cancer $[4,18]$. Thus, Sp1 can be another possible molecular target for tolfenamic acid-induced apoptosis.

In conclusion, this study demonstrated that tolfenamic acid inhibits KB human cancer cell proliferation by inducing
A

Tolfenamic acid( $\mu \mathrm{M}) \quad 0 \quad 50 \quad 75 \quad 100$

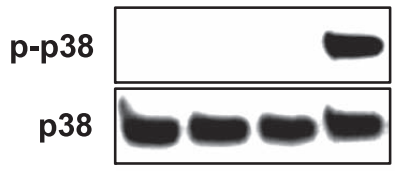

B

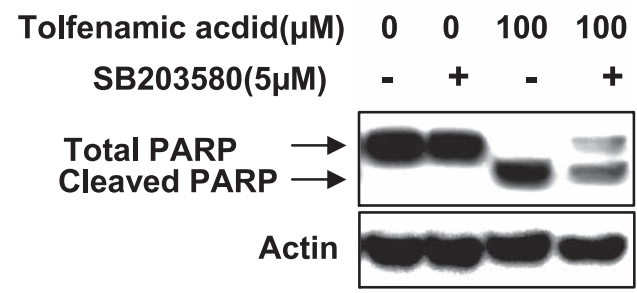

Fig. 5. The effect of tolfenamic acid for $48 \mathrm{~h}$ on $\mathrm{p} 38$ mitogenactivated protein kinase (MAPK) in KB cells A, phospho-MAPKs and total MAPKs were analyzed by Western blot analysis. B, The effect of p38 MAPK inhibition on tolfenamic acid-induced apoptosis. The inhibition of p38 MAPK $(5 \mu \mathrm{M})$ protected cell against tolfenamic acid-induced apoptosis.

apoptosis through the depolarization of MMP in a COXindependent manner. This is associated with the activation of the $\mathrm{p} 38$ MAPK pathway. Therefore, it was concluded that the apoptotic mechanism of tolfenamic acid in KB cells might be mediated by a mitochondria-driven apoptotic pathway through p38 MAPK. Overall, tolfenamic acid may be a good candidate for cancer treatment.

\section{Acknowledgments}

This study was supported by Bio R\&D program through the Korea Science and Engineering Foundation funded by the Ministry of Education, Science and Technology (M10870050003-08N7005-00311). Also, this study was conducted in part by research funds from Gwangju University, South Korea in 2010.

\section{References}

[1] Agrawal, A. and Fentiman, I.S.: NSAIDs and breast cancer: a possible prevention and treatment strategy. Int. J. Clin. Pract., 62, 444-449, 2008.

[2] Simon, L.S., Weaver, A.L., Graham, D.Y., Kivitz, A.J., Lipsky, P.E., Hubbard, R.C., Isakson, P.C., Verburg, K.M., Yu, S.S., Zhao, W.W., and Geis, G.S.: Anti-inflammatory and upper gastrointestinal effects of celecoxib in rheumatoid arthritis: a randomized controlled trial. JAMA, 282, 19211928, 1999. 
[3] Liu, C.H., Chang, S.H., Narko, K., Trifan, O.C., Wu, M.T., Smith, E., Haudenschild, C., Lane, T.F., and Hla, T.: Overexpression of cyclooxygenase- 2 is sufficient to induce tumorigenesis in transgenic mice. J. Biol. Chem., 276, 18563-18569, 2001.

[4] Abdelrahim, M., Baker, C.H., Abbruzzese, J.L., SheikhHamad, D., Liu, S., Cho, S.D., Yoon, K., and Safe, S.: Regulation of vascular endothelial growth factor receptor-1 expression by specificity proteins 1,3 , and 4 in pancreatic cancer cells. Cancer Res., 67, 3286-3294, 2007.

[5] Chan, G., Boyle, J.O., Yang, E.K., Zhang, F., Sacks, P.G., Shah, J.P., Edelstein, D., Soslow, R.A., Koki, A.T., Woerner, B.M., Masferrer, J.L., and Dannenberg, A.J.: Cyclooxygenase2 expression is up-regulated in squamous cell carcinoma of the head and neck. Cancer Res., 59, 991-994, 1999.

[6] Ferrandina, G., Legge, F., Ranelletti, F.O., Zannoni, G.F., Maggiano, N., Evangelisti, A., Mancuso, S., Scambia, G., and Lauriola, L.: Cyclooxygenase-2 expression in endometrial carcinoma: correlation with clinicopathologic parameters and clinical outcome. Cancer, 95, 801-807, 2002.

[7] Khuri, F.R., Wu, H., Lee, J.J., Kemp, B.L., Lotan, R., Lippman, S.M., Feng, L., Hong, W.K., and Xu, X.C.: Cyclooxygenase-2 overexpression is a marker of poor prognosis in stage I non-small cell lung cancer. Clin. Cancer Res., 7, 861-867, 2001.

[8] Maitra, A., Ashfaq, R., Gunn, C.R., Rahman, A., Yeo, C.J., Sohn, T.A., Cameron, J.L., Hruban, R.H., and Wilentz, R.E.: Cyclooxygenase 2 expression in pancreatic adenocarcinoma and pancreatic intraepithelial neoplasia: an immunohistochemical analysis with automated cellular imaging. Am. J. Clin. Pathol., 118, 194-201, 2002.

[9] Marrogi, A., Pass, H.I., Khan, M., Metheny-Barlow, L.J., Harris, C.C., and Gerwin, B.I.: Human mesothelioma samples overexpress both cyclooxygenase-2 (COX-2) and inducible nitric oxide synthase (NOS2): in vitro antiproliferative effects of a COX-2 inhibitor. Cancer Res., 60, 36963700, 2000.

[10] Shiota, G., Okubo, M., Noumi, T., Noguchi, N., Oyama, K., Takano, Y., Yashima, K., Kishimoto, Y., and Kawasaki, H.: Cyclooxygenase-2 expression in hepatocellular carcinoma. Hepatogastroenterology, 46, 407-412, 1999.

[11] Shirahama, T.: Cyclooxygenase-2 expression is up-regulated in transitional cell carcinoma and its preneoplastic lesions in the human urinary bladder. Clin. Cancer Res., 6, 2424-2430, 2000.

[12] Shono, T., Tofilon, P.J., Bruner, J.M., Owolabi, O., and Lang, F.F.: Cyclooxygenase-2 expression in human gliomas: prognostic significance and molecular correlations. Cancer Res., 61, 4375-4381, 2001.

[13] He, T.C., Chan, T.A., Vogelstein, B., and Kinzler, K.W.: PPARdelta is an APC-regulated target of nonsteroidal antiinflammatory drugs. Cell, 99, 335-345, 1999.

[14] Zhang, L., Yu, J., Park, B.H., Kinzler, K.W., and Vogelstein, B.: Role of BAX in the apoptotic response to anticancer agents. Science, 290, 989-992, 2000.

[15] Eskerod, O.: Gastrointestinal tolerance studies on tolfenamic acid in humans and animals. Pharmacol Toxicol., 75 Suppl. 2, 44-48, 1994.

[16] Isomäki, H., Martio, J., Kaarela, K., Kajander, A., Koota, K.,
Lehtinen, K., Luukkainen, R., Martio, T., Nissilä, M., Nuotio, P., and Sarna, S.: Comparison of the analgesic effect of ten nonsteroidal anti-inflammatory drugs. Br. J. Rheumatol., 23, 61-65, 1984.

[17] Keinanen, S., Simila, S., and Kouvalainen, K.: Oral antipyretic therapy: evaluation of the $\mathrm{N}$-aryl-anthranilic acid derivatives mefenamic acid, tolfenamic acid and flufenamic acid. Eur. J. Clin. Pharmacol., 13, 331-344, 1978.

[18] Abdelrahim, M., Baker, C.H., Abbruzzese, J.L., and Safe, S.: Tolfenamic acid and pancreatic cancer growth, angiogenesis, and Sp protein degradation. J. Natl. Cancer Inst., 98, 855868, 2006.

[19] Lee, S.H., Bahn, J.H., Choi, C.K., Whitlock, N.C., English, A.E., Safe, S., and Baek, S.J.: ESE-1/EGR-1 pathway plays a role in tolfenamic acid-induced apoptosis in colorectal cancer cells. Mol. Cancer Ther., 7, 3739-3750, 2008.

[20] Ichijo, H., Nishida, E., Irie, K., ten Dijke, P., Saitoh, M., Moriguchi, T., Takagi, M., Matsumoto, K., Miyazono, K., and Gotoh, Y.: Induction of apoptosis by ASK1, a mammalian MAPKKK that activates SAPK/JNK and p38 signaling pathways. Science, 275, 90-94, 1997.

[21] Yang, J., Liu, X., Bhalla, K., Kim, C.N., Ibrado, A.M., Cai, J., Peng, T.I., Jones, D.P., and Wang, X.: Prevention of apoptosis by Bcl-2: release of cytochrome c from mitochondria blocked. Science, 275, 1129-1132, 1997.

[22] Hansen, P.E.: Tolfenamic acid in acute and prophylactic treatment of migraine: a review. Pharmacol. Toxicol., 75 Suppl. 2, 81-82, 1994.

[23] Van Laethem, A., Van Kelst, S., Lippens, S., Declercq, W., Vandenabeele, P., Janssens, S., Vandenheede, J.R., Garmyn, M., and Agostinis, P.: Activation of p38 MAPK is required for Bax translocation to mitochondria, cytochrome c release and apoptosis induced by UVB irradiation in human keratinocytes. FASEB J., 18, 1946-1948, 2004.

[24] Kim, B.S., Yoon, K.H., Oh, H.M., Choi, E.Y., Kim, S.W., Han, W.C., Kim, E.A., Choi, S.C., Kim, T.H., Yun, K.J., Kim, E.C., Lyou, J.H., Nah, Y.H., Chung, H.T., Cha, Y.N., and Jun, C.D.: Involvement of p38 MAP kinase during iron chelator-mediated apoptotic cell death. Cell Immunol., 220, 96-106, 2002.

[25] Park, M.T., Choi, J.A., Kim, M.J., Um, H.D., Bae, S., Kang, C.M., Cho, C.K., Kang, S., Chung, H.Y., Lee, Y.S., and Lee, S.J.: Suppression of extracellular signal-related kinase and activation of p38 MAPK are two critical events leading to caspase-8- and mitochondria-mediated cell death in phytosphingosine-treated human cancer cells. J. Biol. Chem., 278, 50624-50634, 2003.

[26] Mandal, C., Dutta, A., Mallick, A., Chandra, S., Misra, L., Sangwan, R.S., and Mandal, C.: Withaferin A induces apoptosis by activating p38 mitogen-activated protein kinase signaling cascade in leukemic cells of lymphoid and myeloid origin through mitochondrial death cascade. Apoptosis, 13, 1450-1464, 2008.

[27] Papineni, S., Chintharlapalli, S., Abdelrahim, M., Lee, S.O., Burghardt, R., Abudayyeh, A., Baker, C., Herrera, L., and Safe, S.: Tolfenamic acid inhibits esophageal cancer through repression of specificity proteins and c-Met. Carcinogenesis, 30, 1193-1201, 2009. 